\title{
Analysis of the Surface Treatments Effect on the Creep Behavior of Ti-6Al-4V Alloy
}

\author{
G. F. C. Almeida Alb $*$ (D, T. Sugahara $^{c}$, A. A. Arbex ${ }^{b}$, A. A. Couto ${ }^{a, b}$ (D), M. Massi ${ }^{b}$, F. E. Montoro ${ }^{d}$, \\ D. A. P. Reis ${ }^{c}$ (D) \\ anstituto de Pesquisas Energéticas e Nucleares (IPEN), Centro de Ciência e Tecnologia de Materiais, \\ 05508-000, São Paulo, SP, Brasil \\ ${ }^{b}$ Universidade Presbiteriana Mackenzie (UPM), Escola de Engenharia, 01302-907, São Paulo, SP, Brasil \\ ${ }^{c}$ Universidade Federal de São Paulo (UNIFESP), Departamento de Ciência e Tecnologia, 12231-280, \\ São José dos Campos, SP, Brasil \\ ${ }^{d}$ Centro Nacional de Pesquisa em Energia e Materiais (CNPEM), Laboratório de Microscopia \\ Eletrônica, LME/LNNano, 13083-100, Campinas, SP, Brasil
}

Received: July 15, 2020; Revised: October 19, 2020; Accepted: November 02, 2020

\begin{abstract}
This paper compares the creep behavior of Ti-6Al-4V alloy after different surface treatments, the plasma nitriding using Plasma Enhanced Chemical Vapor Deposition (PECVD), and the deposition of $\mathrm{SiC}$ thin films with $\mathrm{Cr}$ interlayer using High Power Impulse Magnetron Sputtering (HiPIMS). A microstructural characterization was performed with Scanning Electron Microscopy (SEM), Scanning and Transmission Electron Microscopy (STEM), and Energy Dispersive Spectroscopy (EDS) techniques. The creep test was performed at a constant load from 500 to $600{ }^{\circ} \mathrm{C}$ and 125 to $319 \mathrm{MPa}$, and a fractographic analysis was performed. The EDS analysis of the plasma nitrided layer indicated the nitrogen presence of the compounds $\mathrm{TiN}$ and $\mathrm{Ti}_{2} \mathrm{~N}$ and an increase in the iron concentration. Creep test results in both conditions indicated an increase in the creep resistance. Plasma nitrided condition indicated the lowest creep rate and lesser elongation, making it the most suitable in applications that require a low dimensional distortion.
\end{abstract}

Keywords: Ti-6Al-4V, SiC film, HiPIMS, plasma nitriding, Creep.

\section{Introduction}

Ti-6Al-4V alloy is one of the most widely used titanium alloys. It is widely used in the aeronautical industry due to its good creep resistance ${ }^{1-3}$. However, titanium suffers from oxidation and for high-temperature applications a surface treatment, that acts as an oxygen diffusion barrier, is indicated to maintain good mechanical strength ${ }^{2,4}$.

Currently, the most frequent difficulties found in the research of these materials are the adhesion problems during the thermal cycle and the diffusion of the coating elements in the substrate ${ }^{5,6}$. Among all technologies considered, surface modifications with plasma processes have gained prominence for the relatively low cost and the possibility of application in complex geometries ${ }^{7}$.

The Ti-6Al-4V alloy can be heat treated and acquire microstructures besides equiaxial, such as martensitic, bimodal and Widmanstätten. Comparing to the other microstructures, the Widmanstätten microstructure previously studied ${ }^{8-11}$ had the highest creep resistance in Ti-6Al-4V alloy. This fact can be attributed to the $\alpha / \beta$ interfaces that act as obstacles to the dislocations slip and the larger grain size that reduces the grain boundary sliding ${ }^{12}$.

From the Widmanstätten microstructural condition, this paper discusses the effect of two different types of surface

*e-mail address: gisele_fab@hotmail.com treatments and their effects on the creep behavior of Ti-6Al$4 \mathrm{~V}$ alloy. The treatments are the plasma nitriding and $\mathrm{SiC}$ film alloy coating with $\mathrm{Cr}$ interlayer by HiPIMS.

Surface treatments of plasma nitriding ${ }^{9,13}$ and the application of Cr interlayer SiC film deposited by HiPIMS ${ }^{14,15}$ have been studied by this research group and the objective of this work is to verify under what conditions each one of them may be considered more appropriate.

\section{Materials and Methods}

\subsection{Sample preparation}

Figure 1 shows the geometry and dimensions of the specimens applied in the creep tests. The specimens were made according to the ASTM E139-11 $1{ }^{16}$ specifications, using extensometers to measure the creep strain.

\subsection{Material heat treatment}

The Ti-6Al-4V alloy was heat-treated at $1050{ }^{\circ} \mathrm{C}$ for 30 minutes in Argon atmosphere, followed by furnace cooling to obtain the Widmanstätten microstructure.

\subsection{Surface treatment}

The material in the form of cylindrical bars was used to cut small samples with approximately $5 \mathrm{~mm}$ of thickness 


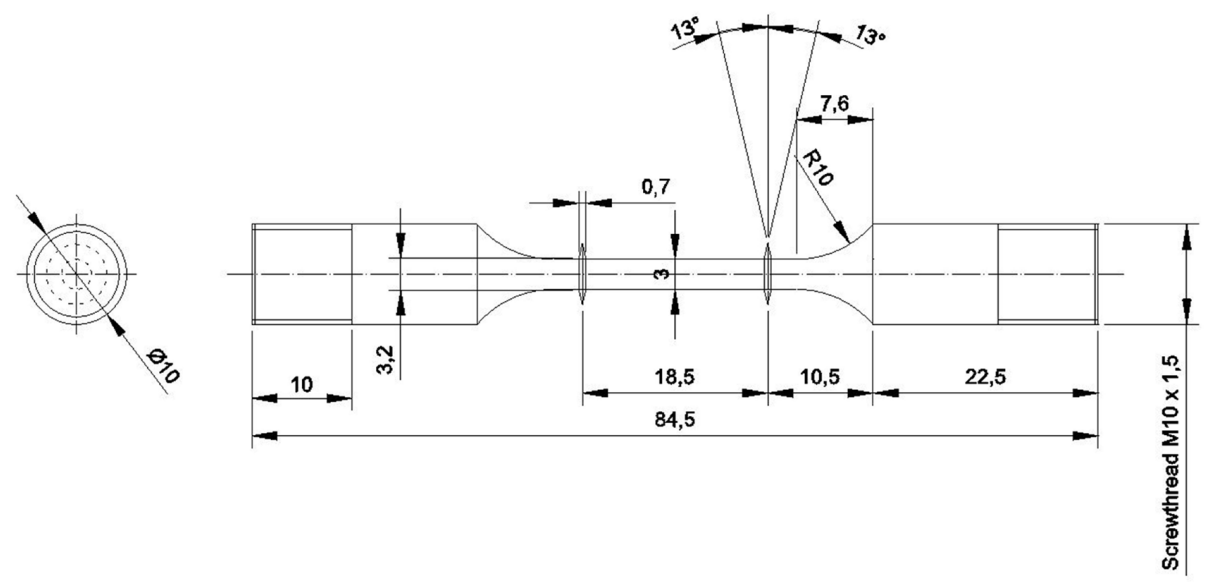

Figure 1. Creep specimen (dimensions in $\mathrm{mm})^{13}$.

Table 1. Parameters applied in the plasma nitriding.

\begin{tabular}{cccccc}
\hline Temperature $\left({ }^{\circ} \mathrm{C}\right)$ & Atmosphere $\left(\mathrm{Ar} / \mathrm{H}_{2} / \mathrm{N}_{2}\right)(\%)$ & Pressure $(\mathrm{Pa})$ & Voltage $(\mathrm{V})$ & Electric current $(\mathrm{A})$ & Power $(\mathrm{W})$ \\
\hline 690 & $0.455 / 0.455 / 0.090$ & 425 & 475 & 2.2 & 1125 \\
\hline
\end{tabular}

Table 2. Parameters used to deposit the $\mathrm{SiC} / \mathrm{Cr}$ film on Ti-6Al-4V samples.

\begin{tabular}{cccccc}
\hline \multirow{2}{*}{ Target / substrate distance } & \multicolumn{2}{c}{$\mathrm{Cr}$} & & \multicolumn{2}{c}{$\mathrm{SiC}$} \\
\cline { 2 - 3 } \cline { 5 - 6 } & Average Power & Deposition time & & Average Power & Deposition time \\
\hline $155 \mathrm{~mm}$ & $200 \mathrm{~W}$ & $0.5 \mathrm{~h}$ & & $300 \mathrm{~W}$ & $2 \mathrm{~h}$ \\
\hline
\end{tabular}

for testing the surface treatment parameters, and to machine the specimens used in the creep tests.

Two processes were performed: plasma nitriding and silicon carbide $(\mathrm{SiC})$ deposition with chrome interlayer in the specimens, which will be described below. In both cases, it was necessary to develop a specific reactor sample holder for the treatment of creep specimens.

\subsubsection{Plasma nitriding}

The plasma nitriding process was carried out in a reactor consisting of a hermetic chamber of cylindrical shape. This equipment was developed by the Laboratory of Plasmas and Processes (LPP) of Technological Institute of Aeronautics (ITA). The power supply used was the DC current source from Supplier Electronics (Brazil). The nitriding process parameters are described in Table 1. Figure 2 shows the sample holder design, developed for the nitriding of the creep specimens and the photography of the ten creep specimens and four pellet-shaped samples after the plasma nitriding.

\subsubsection{SiC/Cr film deposition by HiPIMS}

For the depositions, a cylindrical reactor produced in stainless steel was used with a chamber of $500 \mathrm{~mm}$ in diameter and $300 \mathrm{~mm}$ in length. It has two magnetron cathodes capable of storing two targets of $101.6 \mathrm{~mm}$ diameter. A pulsed power source called HiPIMS (High Power Impulse Magnetron Sputtering), from Solvix-Peoleand Power Electronics (Switzerland) was used to deposit SiC films, and a DC power supply to $\mathrm{Cr}$ interlayer depositions.

To condition the pellet-shaped sample, the reactor has a sample holder where the substrate is fixed under a rail on which it can slide allowing the variation of the distance between target / substrate.

In the case of creep specimens, it was necessary to develop and manufacture a new sample holder. It was made in a cylindrical shape with a threaded fitting so that the specimen could be threaded and rotated during the deposition. A stepper motor was coupled to the sample holder so that it rotated during the process and ensured the deposition homogeneity throughout the specimen.

Table 2 shows the parameters used for the $\mathrm{SiC}$ film deposition with $\mathrm{Cr}$ interlayer on Ti-6Al-4V samples.

Other parameters such as $20 \mathrm{sccm}$ argon flow rate, $0.67 \mathrm{~Pa}$ of working pressure, $500 \mathrm{~Hz}$ of frequency, $100 \mu \mathrm{s}$ of pulse width and 15 minutes of pre sputtering were used in the $\mathrm{SiC}$ depositions.

\subsection{Creep tests}

The tests were conducted under a constant load of 125 , 250 , and $319 \mathrm{MPa}$ at temperatures of $500{ }^{\circ} \mathrm{C}$ and $600{ }^{\circ} \mathrm{C}$ in a Mayes furnace model. A Linear Variable Differential Transformer (LVDT) was used to measure the strain and a thermocouple fixed to the specimen center was used to measure the temperature.

\subsection{Microstructural characterization}

The microstructural characterization and observation of the layers formed after the plasma nitriding and the $\mathrm{SiC} / \mathrm{Cr}$ coating were performed in a scanning electron microscope (SEM). After the creep tests, the fracture surfaces of the specimens were also analyzed by SEM techniques.

The characterization of the alloy surface was performed in a Scanning Transmission Electron Microscopy (STEM). 
One lamella of the Ti-6Al-4V sample with the SiC film and one of the plasma nitrided alloy were produced by focused ion beam (FIB) technique using a dual-beam electron microscope model FEI Helios 660 - Nanolab at the Brazilian Nanotechnology National Laboratory (LNNano) at the campus of the Brazilian Center Research in Energy and Materials (CNPEM), in the city of Campinas / SP. This SEM has an electron gun that allows imaging and a gallium ion gun that removes sample material (lamella). This makes it possible to cut, remove and polish the lamella, allowing for the preparation of extremely thin specimens (lamella usually with less than $100 \mathrm{~nm}$ in thickness), which can be analyzed by transmission or scanning transmission electron microscopy.

After the preparation of the lamellas by FIB, the samples were analyzed by the STEM technique. This analysis allowed the characterization of the alloy surface with cross-sectional images of the sample, allowing the view of the Ti-6Al-4V substrate, $\mathrm{Cr}$ interlayer, and $\mathrm{SiC}$ film and the nitride layer and the qualitative analysis of the chemical elements present via Energy Dispersive Spectroscopy (EDS).

\section{Results and Discussion}

\subsection{Surface layer}

After obtaining the Widmanstätten microstructure, part of the material was coated with $\mathrm{SiC} / \mathrm{Cr}$ and part was plasma nitrided. Figure 3 shows the images of these two different layers performed by STEM.

Sugahara et al. ${ }^{14}$ previously measured the thickness value of each film in the $\mathrm{SiC}$ film with $\mathrm{Cr}$ interlayer (Figure 3a).

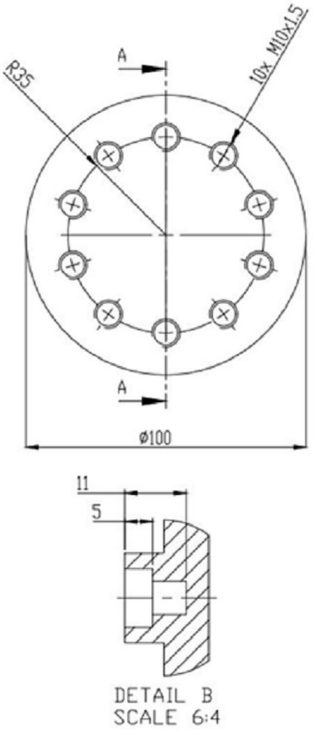

(a)
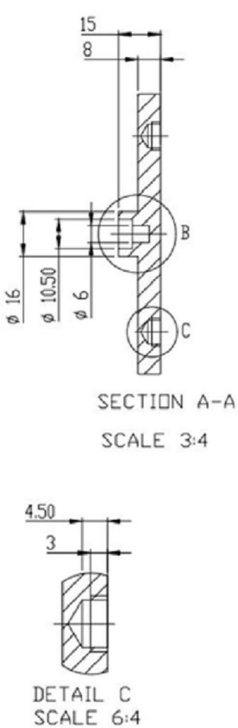

SCALE $6: 4$

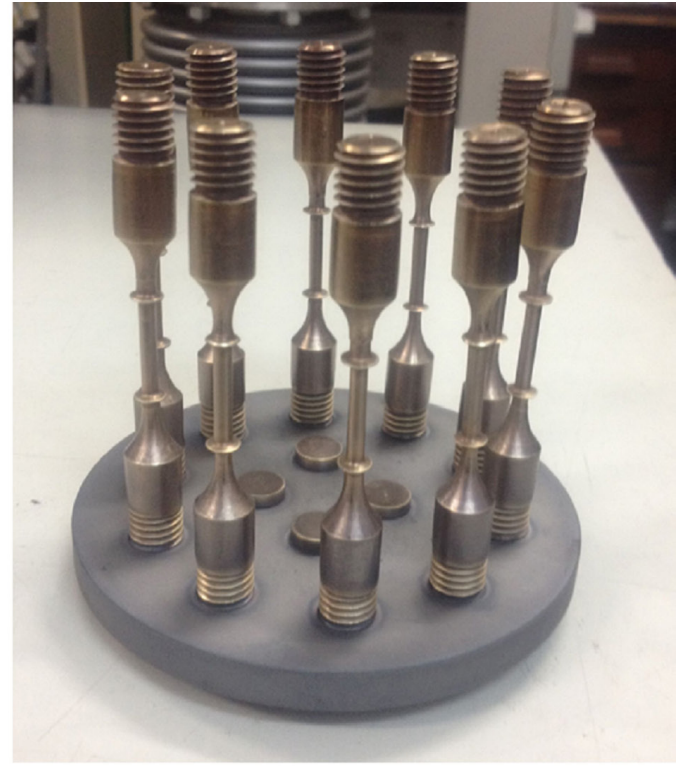

(b)

Figure 2. (a) Sample holder draw used for plasma nitriding (dimensions in $\mathrm{mm}$ ) and (b) photograph of the creep specimens after plasma nitriding.

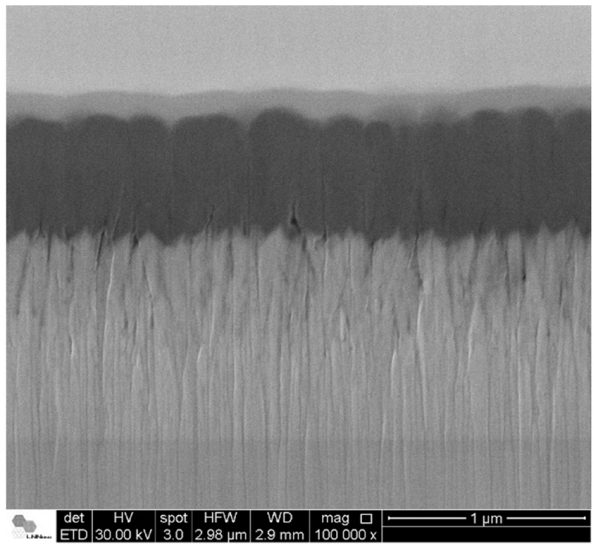

(a)

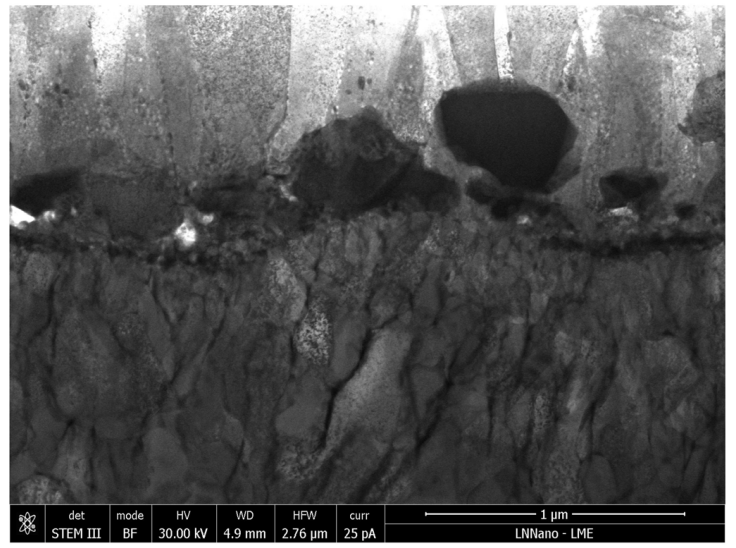

(b)

Figure 3. STEM image (a) of the morphology of the $\mathrm{Cr}$ interlayer SiC film and (b) of the layer formed by plasma nitriding. 
The thickness of the SiC film, image darker region, was $0.6 \mu \mathrm{m}$ and the Cr interlayer, lighter region just below was $1.05 \mu \mathrm{m}$. It results in a total thickness of approximately $1.67 \mu \mathrm{m}$.

The nitrided layer (Figure $3 b$ ) has a thickness of approximately $1.0 \mu \mathrm{m}$, it is consistent with the measured performed by Almeida et al. ${ }^{13}$ in a SEM micrography of the same material. This external layer can be called compound layer. Just below it can be seen part of the second layer that has approximately $4.0 \mu \mathrm{m}$ and can be called as diffusion layer. Lima et al. ${ }^{17}$ performed a phase identification of the Ti-6Al-4V samples nitrided layer, nitrided at $700{ }^{\circ} \mathrm{C}$ for 4 hours with a nitrogen concentration of $50 \%$, combining the results from Rietveld analysis, Grazing incidence x-ray diffraction in multiple angles (MA-GIXRD), and Nuclear reaction analysis (NRA). They found an upper fine-grained layer of $\delta$-TiN in a layer of $0,5 \mu \mathrm{m}$ followed by a layer of $\sim 2 \mu \mathrm{m}$ related to to $\varepsilon-\mathrm{Ti}_{2} \mathrm{~N}$ with the possibility of $\delta$-TiN extending to the lower layer.
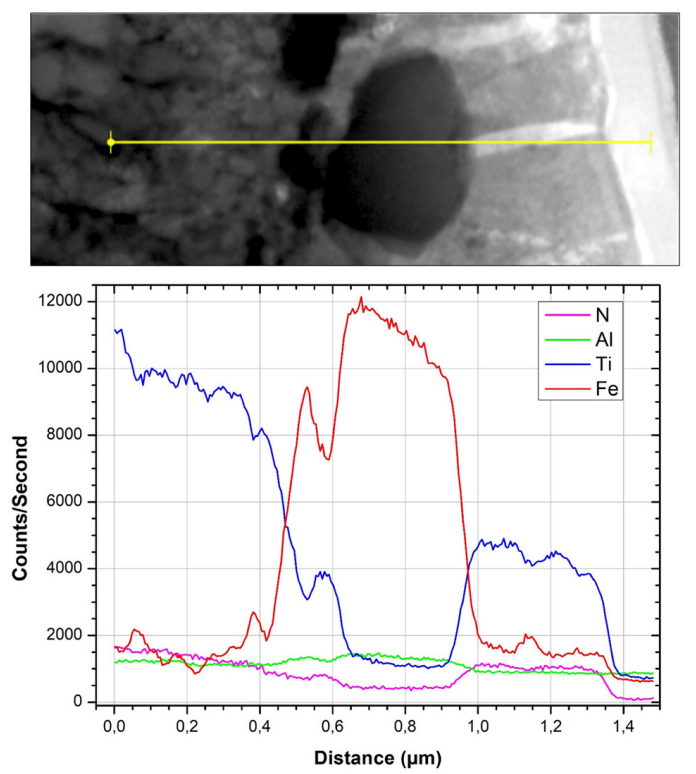

Figure 4. EDS analysis of the layer formed by plasma nitriding of the sample prepared by FIB.
Figure 4 shows the EDS analysis of the plasma nitrided layer. $\mathrm{X}$-axis display the distance in $\mu \mathrm{m}$ and the $\mathrm{y}$-axis display the intensity in counts per second (cps). When observing the nitride layer, a reduction in the titanium concentration can be noticed due to the formation of nitrides. The formed compounds were identified in previous work by X-ray diffraction and are the $\delta$-TiN with face centered cubic structure (fcc) and the $\varepsilon-\mathrm{Ti}_{2} \mathrm{~N}$ with tetragonal structure ${ }^{13}$. Grill et al. ${ }^{18}$ report that the nitrided layer is divided in an compound layer and a diffusion layer. The compounds layer was formed by the $\delta$-TiN and $\varepsilon-\mathrm{Ti}_{2} \mathrm{~N}$ phases, while the diffusion layer was formed by the $\varepsilon-\mathrm{Ti}_{2} \mathrm{~N}$ and $\alpha^{\prime}-(\mathrm{Ti}, \mathrm{N})$ phases. Being the $\alpha$ ' phase, a solid solution of nitrogen in titanium.

The nitrogen diffusion in the metallic substrate could explain the reduction of aluminum in the surface area. The diffusion into the aluminum, in other words, its removal out of the diffusing layer in the surface, can cause its absence not only in the TiN and $\mathrm{Ti}_{2} \mathrm{~N}$ sub-layers but also in the $\alpha$-Ti according to Morgiel and Wierzchon ${ }^{19}$.

It was also possible to visualize a substantial increase in $\mathrm{Fe}$ concentration between the layers, this was also reported by Raveh et al. ${ }^{20}$ who classified this as segregated elements between the layers. Probably this element had its concentration increased due to the chamber reactor, made of a Fe-based alloy.

\subsection{Creep tests results}

Table 3 exhibits the experimental results of the specimens tested at temperatures of 500 and $600{ }^{\circ} \mathrm{C}$ and stresses of $125 \mathrm{MPa}, 250$ and $319 \mathrm{MPa}$. All the specimens have a Widmanstätten microstructure and are identified as $\mathrm{Wd}^{21}$ for the untreated condition, $\mathrm{Wd}+\mathrm{NP}^{13}$ for the plasma nitrided and $\mathrm{Wd}+\mathrm{SiC}$ for the samples coated with $\mathrm{SiC}^{22}$. The primary creep time $\left(\mathrm{t}_{\mathrm{p}}\right)$, secondary creep rate $\left(\dot{\varepsilon}_{s}\right)$, final creep time $\left(\mathrm{t}_{\mathrm{f}}\right)$, and final strain $\left(\varepsilon_{f}\right)$ are detailed.

Figure 5 shows the creep tests experimental curves at $500{ }^{\circ} \mathrm{C}$ and $319 \mathrm{MPa}$, and at $600{ }^{\circ} \mathrm{C}$ with 125,250 and $319 \mathrm{MPa}$ with Widmanstätten structure comparing the untreated $(\mathrm{Wd})^{21}$, plasma nitrided $(\mathrm{Wd}+\mathrm{NP})^{13}$ and with $\mathrm{SiC}$ coated $(\mathrm{Wd}+\mathrm{SiC})^{22}$.

The secondary creep rate decreases compared to the untreated condition for both studied conditions, which indicates that the creep resistance of the material increases due

Table 3. Ti-6Al-4V creep test results in the conditions untreated $(\mathrm{Wd})^{21}$, plasma nitrided $(\mathrm{Wd}+\mathrm{NP})^{13}$ and $\mathrm{SiC}$ coated $(\mathrm{Wd}+\mathrm{SiC})^{22}$.

\begin{tabular}{|c|c|c|c|c|c|c|}
\hline $\begin{array}{c}\text { Temperature } \\
\left({ }^{\circ} \mathbf{C}\right)\end{array}$ & Stress (MPa) & Conditions & tp (h) & $\dot{\varepsilon}_{s}(1 / \mathbf{h})$ & tf (h) & $\varepsilon f(\mathrm{~mm} / \mathrm{mm})$ \\
\hline \multirow{3}{*}{500} & \multirow{3}{*}{319} & $\mathrm{Wd}$ & 16.000 & 0.00035 & 224.00 & 0.112 \\
\hline & & $\mathrm{Wd}+\mathrm{NP}$ & 8.300 & 0.00008 & 251.27 & 0.038 \\
\hline & & $\mathrm{Wd}+\mathrm{SiC}$ & 28.000 & 0.00024 & 199.00 & 0.071 \\
\hline \multirow{9}{*}{600} & \multirow{3}{*}{125} & $\mathrm{Wd}$ & 9.000 & 0.00140 & 102.12 & 0.286 \\
\hline & & $\mathrm{Wd}+\mathrm{NP}$ & 4.000 & 0.00038 & 112.56 & 0.464 \\
\hline & & $\mathrm{Wd}+\mathrm{SiC}$ & 20.000 & 0.00100 & 134.00 & 0.284 \\
\hline & \multirow{3}{*}{250} & Wd & 0.350 & 0.03040 & 2.03 & 0.098 \\
\hline & & $\mathrm{Wd}+\mathrm{NP}$ & 0.417 & 0.00367 & 6.03 & 0.031 \\
\hline & & $\mathrm{Wd}+\mathrm{SiC}$ & 0.680 & 0.02000 & 4.93 & 0.170 \\
\hline & \multirow{3}{*}{319} & $\mathrm{Wd}$ & 0.067 & 0.16000 & 0.62 & 0.237 \\
\hline & & $\mathrm{Wd}+\mathrm{NP}$ & 0.042 & 0.02070 & 1.17 & 0.056 \\
\hline & & $\mathrm{Wd}+\mathrm{SiC}$ & 0.150 & 0.06350 & 1.40 & 0.175 \\
\hline
\end{tabular}


$500^{\circ} \mathrm{C}-319 \mathrm{MPa}$

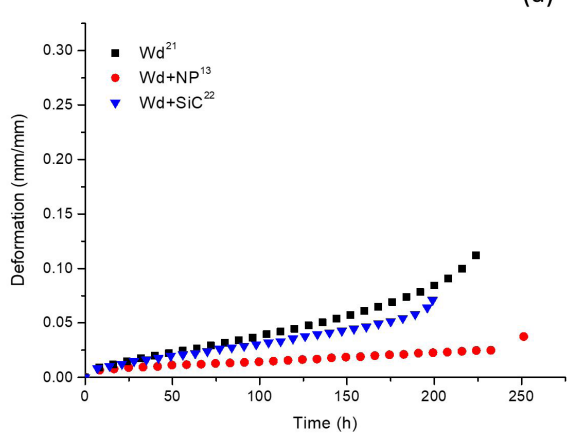

$600^{\circ} \mathrm{C}-250 \mathrm{MPa}$

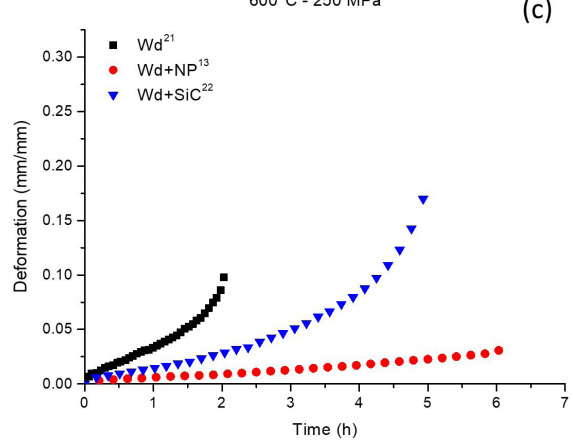

(a)

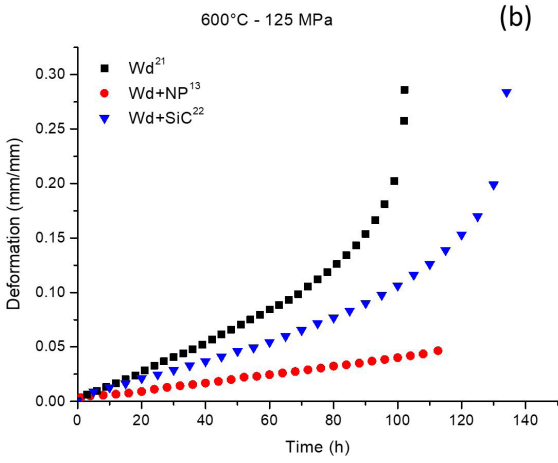

$600^{\circ} \mathrm{C}-319 \mathrm{MPa}$

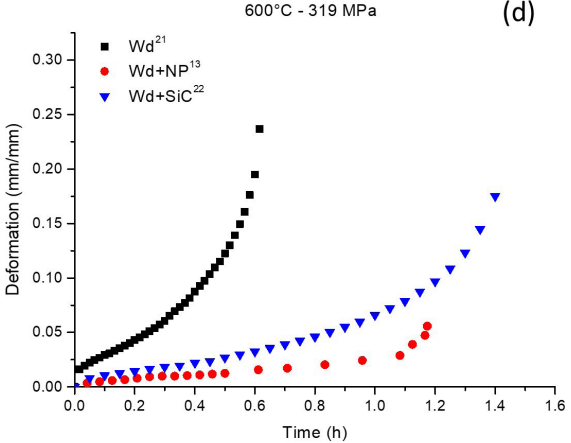

Figure 5. Ti-6Al-4V creep curves with Widmanstätten structure, untreated (Wd)21, plasma nitrided $(\mathrm{Wd}+\mathrm{NP})^{13}$ and $\mathrm{SiC}$ coated $(\mathrm{Wd}+\mathrm{SiC})^{22}$ under the conditions: (a) $500{ }^{\circ} \mathrm{C}$ and $319 \mathrm{MPa}$, (b) $600{ }^{\circ} \mathrm{C}$ and $125 \mathrm{MPa}$, (c) $600{ }^{\circ} \mathrm{C}$ and $250 \mathrm{MPa}$ and (d) $600{ }^{\circ} \mathrm{C}$ and $319 \mathrm{MPa}$.

to the surface modifications. This improvement in the creep resistance is also obtained with other surface treatments ${ }^{2,11,23}$, because they all improve the oxidation resistance.

For the plasma nitrided condition, this rate reduction was higher than in the $\mathrm{SiC}$ coated condition. Figure 6 shows the comparisons of the secondary creep rate reduction percentage for the conditions studied.

Regarding the material life, it was found that, under the test conditions at $600^{\circ} \mathrm{C}$ with 125 and $319 \mathrm{MPa}$, there was a reduction in the fracture time of nitrided sample compared to $\mathrm{SiC}$ coated, which can be attributed to material embrittlement caused by the nitride formed. This embrittlement in the subsurface zone of the component due to oxygen enrichment is related by Sai Srinadh et al. ${ }^{24}$, especially in applications at elevated temperatures, during the long term use.

Figure 7 shows a comparison of the material ductility. The Ti-6Al-4V base material with a Widmanstätten microstructure presents a good ductility. The treatments applied in this alloy modified the surface hardness, which influenced its ductility. It is observed that the plasma nitrided samples suffered the least elongation, which makes it the most suitable in applications that require a little dimensional variation. Reis et al..$^{25}$ also associated the lower ductility of the nitrided samples to the hard surface layer.

\subsection{Fractographic analysis}

Figure 8 shows the Ti-6Al-4V alloy fracture surface after the creep test at $500{ }^{\circ} \mathrm{C}$ and $319 \mathrm{MPa}$. On the $\mathrm{SiC}$ coated material surface, appears more cleavage facets, evidence of a more brittle fracture, which is consistent with the shorter final creep time resulting in this condition when compared to the others. These facets in the fracture surface could be attributed to the easier crack propagation parallel to the lamellar interfaces ${ }^{26}$.

Figure 9 shows the Ti-6Al-4V alloy fracture surface creep tested at $600{ }^{\circ} \mathrm{C}$ and $125 \mathrm{MPa}$. Under both treatment conditions, the fracture surfaces are similar, it is possible to observe a fracture with more ductile characteristics, with apparent dimples and displaying a material contraction. The final creep time of the nitrided sample was shorter compared to SiC coated sample, in this condition.

Figure 10 shows the Ti-6Al-4V alloy fracture surface creep tested at $600{ }^{\circ} \mathrm{C}$ and $250 \mathrm{MPa}$. It can be noted that the fracture of the $\mathrm{SiC}$ coated sample is mixed with facets and dimples, whereas the plasma nitrided sample does not show many deformation marks.

Katani et al. ${ }^{27}$ related a mixed-mode of fracture in Ti-6Al-4V and a large number of micro-voids nucleation mainly in boundary regions between two different phases $(\alpha / \beta)$. These results are in agreement with those reported by Oliveira et al. ${ }^{11}$ in similar conditions of temperature and stress. Seco and Irisarri ${ }^{28}$ suggest in their work that beta grain boundary sliding along the colonies of alpha needles is the operating failure mechanism.

Figure 11 shows the fracture surface of the Ti-6Al$4 \mathrm{~V}$ alloy creep tested at $600{ }^{\circ} \mathrm{C}$ and $319 \mathrm{MPa}$. Under this condition, the $\mathrm{SiC}$ coated sample has more dimples than the plasma nitrided sample.

Briguente ${ }^{21}$ related in your work that the fractographic analyzes of Ti-6Al-4V alloy with Widmanstätten microstructure 


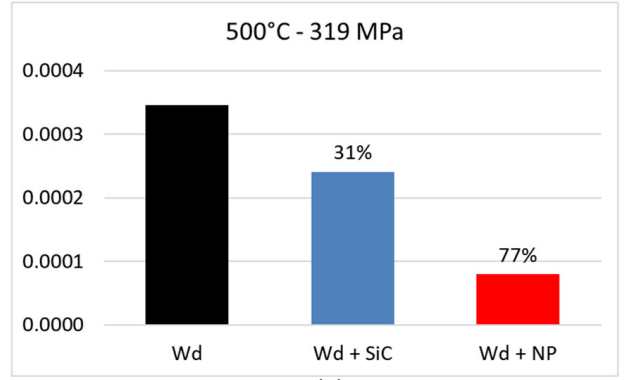

(a)

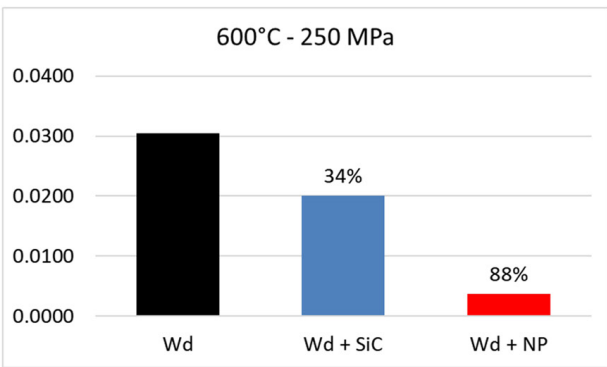

(c)

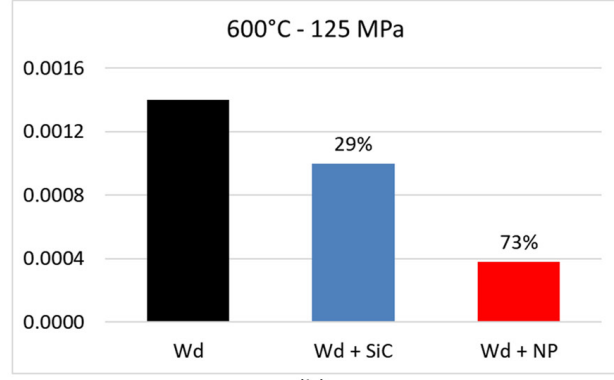

(b)

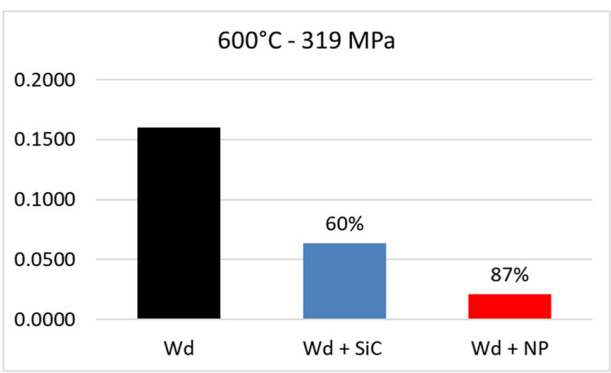

(d)

Figure 6. Comparison of the Ti-6Al-4V alloy creep rate reduction with Widmanstätten structure untreated (Wd) ${ }^{21}$, plasma nitrided (Wd $+\mathrm{NP})^{13}$ and $\mathrm{SiC}$ coated $(\mathrm{Wd}+\mathrm{SiC})^{22}$ in the conditions: (a) $500{ }^{\circ} \mathrm{C}$ and $319 \mathrm{MPa}$, (b) $600{ }^{\circ} \mathrm{C}$ and $125 \mathrm{MPa}$, (c) $600{ }^{\circ} \mathrm{C}$ and $250 \mathrm{MPa}$ and (d) $600{ }^{\circ} \mathrm{C}$ and $319 \mathrm{MPa}$.

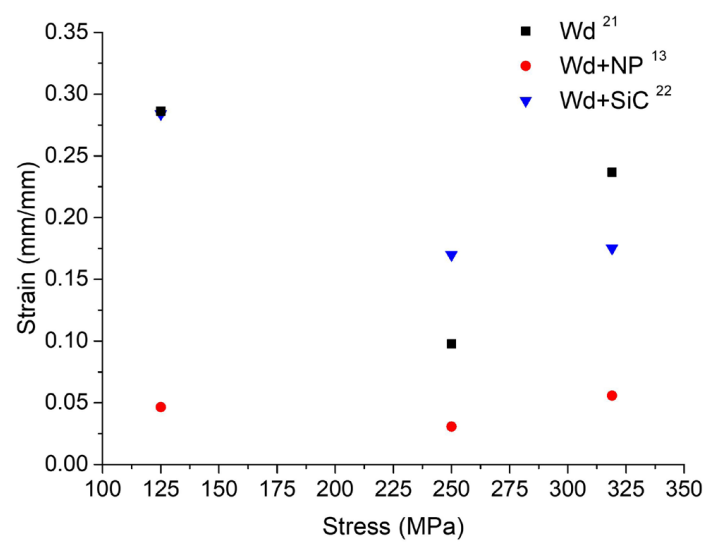

Figure 7. Graph showing strain relationship with stress in the creep test, material ductility calculation at $600{ }^{\circ} \mathrm{C}$.

(a)

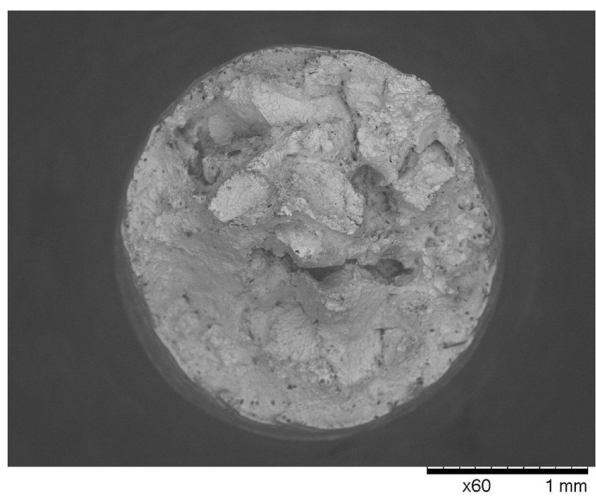

(b) $\quad \mathrm{Wd}+\mathrm{SiC}$

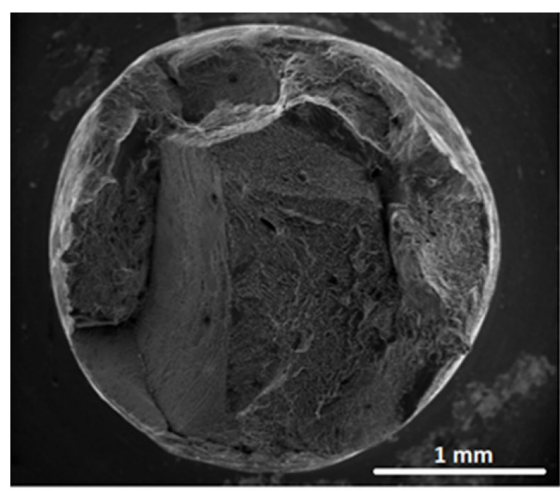

Figure 8. The fracture surface of the Ti-6Al-4V alloy creep tested at $500{ }^{\circ} \mathrm{C}$ and $319 \mathrm{MPa}$, (a) plasma nitrided (Wd $\left.+\mathrm{NP}\right)$ and (b) $\mathrm{SiC}$ coated $(\mathrm{Wd}+\mathrm{SiC})$. 

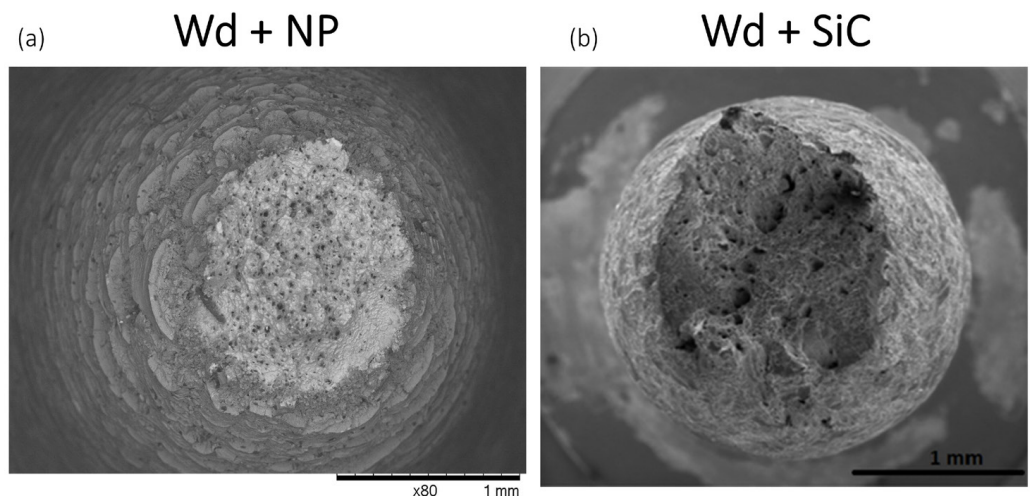

Figure 9. The fracture surface of the Ti-6Al-4V alloy creep tested at $600{ }^{\circ} \mathrm{C}$ and $125 \mathrm{MPa}$, (a) plasma nitrided (Wd $\left.+\mathrm{NP}\right)$ and (b) SiC coated $(\mathrm{Wd}+\mathrm{SiC})$.
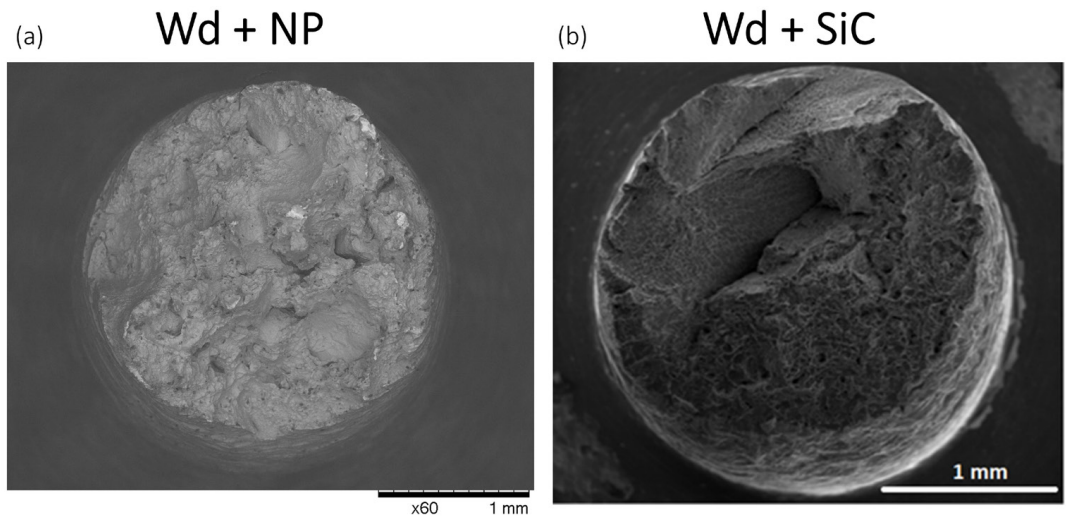

Figure 10. The fracture surface of the Ti-6Al-4V alloy creep tested at $600{ }^{\circ} \mathrm{C}$ and $250 \mathrm{MPa}$, (a) plasma nitrided (Wd $\left.+\mathrm{NP}\right)$ and (b) $\mathrm{SiC}$ coated $(\mathrm{Wd}+\mathrm{SiC})$.
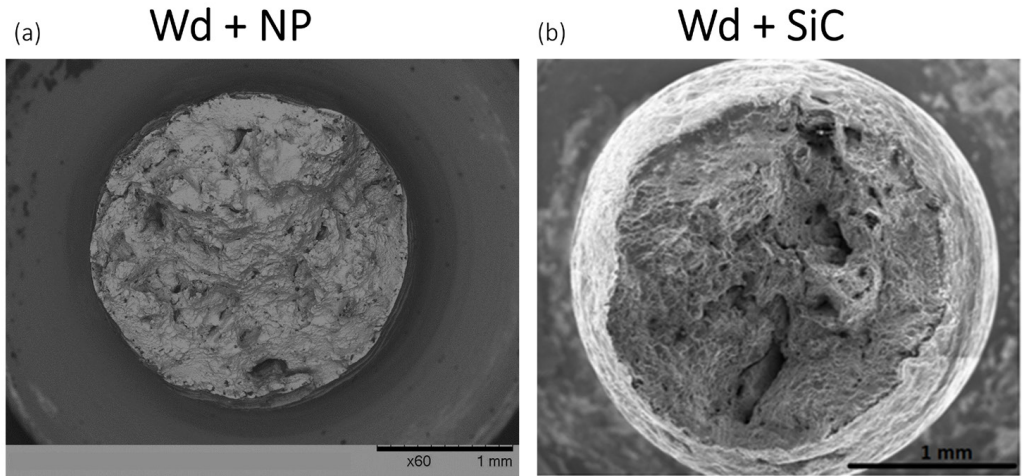

Figure 11. The fracture surface of the Ti-6Al-4V alloy creep tested at $600{ }^{\circ} \mathrm{C}$ and $319 \mathrm{MPa}$, (a) plasma nitrided (Wd $\left.+\mathrm{NP}\right)$ and (b) $\mathrm{SiC}$ coated $(\mathrm{Wd}+\mathrm{SiC})$.

and without surface treatment indicated that the predominant mechanism was characterized by the formation and coalescence of micro-voids with varying shapes and sizes. The ductile fracture mechanism was which prevailed.

\section{Conclusions}

This work about the effects of plasma nitriding and SiC coating with $\mathrm{Cr}$ interlayer treatments applied in the surface of the Ti-6Al-4V alloy led to the conclusions below:
- $\quad$ EDS analysis of the layer formed by the plasma nitriding process indicated the presence of nitrogen from the $\mathrm{TiN}$ and $\mathrm{Ti}_{2} \mathrm{~N}$ compounds and also an increase in iron concentration. This iron was attributed to the reactor material where the treatment was performed.

- An increase in the creep resistance of the material in the both conditions of surface treatment compared to the untreated condition was evident by the decrease of the secondary creep rate. For the plasma nitrided samples this rate reduction was higher than in the $\mathrm{SiC}$ coated samples. 
- Regarding the material final creep time, the reduction in fracture time of nitrided material compared to $\mathrm{SiC}$ coated at $600^{\circ} \mathrm{C}$ under 125 and $319 \mathrm{MPa}$ was attributed to the brittleness of the material caused by the nitride formed. However, in the case of the sample tested at $500{ }^{\circ} \mathrm{C}$ and $319 \mathrm{MPa}$ and at $600^{\circ} \mathrm{C}$ and $250 \mathrm{MPa}$, the fractographic analysis of the material with $\mathrm{SiC}$ coating presents the more faceted fracture, which explains the shorter final creep time under these conditions.

- $\quad$ Concerning the material ductility, the plasma nitrided samples suffered the smaller elongation, making them the most suitable in applications that requires a low dimensional distortion.

\section{Acknowledgments}

Funding: The authors are grateful to research support from CNEN (Comissão Nacional de Energia Nuclear) for the scholarship given to G.F.C. Almeida [grant number 01342.003512/2019]. They also thank the financial support of CAPES and MackPesquisa [grant number 1598 AJURPFMP-147/2014].

Research supported by LNNano - Brazilian Nanotechnology National Laboratory (CNPEM/MCTI) during the use of the Dual Beam microscope Thermo Fisher Scientific/Fei Helios Nanolab 660 open access facility.

\section{References}

1. Gou J, Shen J, Hu S, Tian Y, Liang Y. Microstructure and mechanical properties of as-built and heat-treated Ti-6Al-4V alloy prepared by cold metal transfer additive manufacturing. J Manuf Process. 2019;42:41-50. http://dx.doi.org/10.1016/j. jmapro.2019.04.012.

2. Briguente LANS, Oñoro J, Briguente FP, Resende FA, Reis JL, Reis DAP, et al. The influence of laser nitriding on creep behavior of Ti-4Al-4V alloy with Widmanstätten microstructure. Metals. 2019;9(2):236. http://dx.doi. org/10.3390/met9020236.

3. Saby M, Massoni E, Bozzolo N. A metallurgical approach to individually assess the rheology of alpha and beta phases of Ti-6Al-4V in the two-phase domain. Mater Charact. 2014;89:8892. http://dx.doi.org/10.1016/j.matchar.2014.01.001.

4. Freitas FE, Reis AG, Reis DAP. Evaluation of creep behavior of Ti-6Al-4V alloy with thermal barrier coating deposited by air plasma spray. Tecnol Metal Mater Min. 2019;16.

5. Spies H-J. Surface engineering of aluminium and titanium alloys: an overview. Surf Eng. 2010;26(1-2):126-34. http:// dx.doi.org/10.1179/174329409X451146.

6. Bloyce A, Morton PH, Bell T. Surface engineering of titanium and titanium alloys. In: Cotell CM, Sprague JA, Smidt Jr FA, editors. ASM handbook. Materials Park: ASM International; 1994. p. 835-51.

7. Chu P. Plasma-surface modification of biomaterials. Mater Sci Eng Rep. 2002;36(5-6):143-206. http://dx.doi.org/10.1016/ S0927-796X(02)00004-9.

8. Yogi LM, Sugahara T. Efeito do tratamento térmico na fluência da liga Ti-6Al-4V. Rev Bras Apl Vácuo. 2008;27(4):189-94.

9. Almeida GFC, Couto AA, Reis DAP, Massi M, Silva AS, Lima NB. Estudo da nitretação por plasma na fluência da liga Ti-6Al-4V. Tecnol em Metal Mater e Mineração. 2016;13(4):331-9. http://dx.doi.org/10.4322/2176-1523.1068.
10. Sugahara T, Reis DAP, Moura C No, Barboza MJR, Perez EAC, Piorino F No, et al. The effect of Widmanstätten and equiaxed microstructures of Ti-6Al-4V on the oxidation rate and creep behavior. Mater Sci Forum. 2010;636-637:65762. http://dx.doi.org/10.4028/www.scientific.net/MSF.636637.657

11. Oliveira VMCA, Silva MCL, Pinto CG, Suzuki PA, Machado JPB, Chad VM, et al. Short-term creep properties of Ti-6Al$4 \mathrm{~V}$ alloy subjected to surface plasma carburizing process. J Mater Res Technol. 2015;4(4):359-66. http://dx.doi. org/10.1016/j.jmrt.2015.05.006.

12. Ochonogor OF, Akinlabi ET, Nyembwe D. A review on the effect of creep and microstructural change under elevated temperature of Ti6A14V alloy for turbine engine application. Mater Today Proc. 2017;4(2):250-6. http://dx.doi.org/10.1016/j. matpr.2017.01.019

13. Almeida GFC, Couto AA, Reis DAP, Massi M, Silva A So, Lima NB. Effect of plasma nitriding on the creep and tensile properties of the Ti-6Al-4V alloy. Metals. 2018;8(8):618. http://dx.doi.org/10.3390/met8080618.

14. Sugahara T, Martins GV, Montoro FE, Merij A No, Massi M, Silva A So, et al. Creep behavior evaluation and characterization of $\mathrm{SiC}$ film with $\mathrm{Cr}$ interlayer deposited by HiPIMS in Ti6Al-4V alloy. Surf Coat Tech. 2017;309:410-6. http://dx.doi. org/10.1016/j.surfcoat.2016.11.091.

15. Merij AC, Sugahara T, Martins GV, Silva A So, Reis DAP, Gonçalves PAR, et al. Use of $\mathrm{Cr}$ interlayer to promote the adhesion of SiC films deposited on Ti-6Al-4V by HiPIMS. Mater Res. 2015;18(5):904-7. http://dx.doi.org/10.1590/15161439.313114

16. ASTM: American Society for Testing and Materials. ASTM E139-11: standard test methods for conducting creep, creep rupture, and stress rupture tests of metallic materials. West Conshohocken: ASTM; 2011. p. 11.

17. Lima SC, Hinrichs R, Vasconcellos MAZ. The influence of nitrogen to hydrogen ratio and temperature on thickness and phase composition in plasma nitrided Ti-6AL-4V. Rev Mat. 2019;24(1):e12325.

18. Grill A, Raveh A, Avni R. Layer structure and mechanical properties of low pressure r.f. plasma nitrided Ti-6Al-4V alloy. Surf Coat Tech. 1990;43-44:745-55. http://dx.doi. org/10.1016/0257-8972(90)90017-7.

19. Morgiel J, Wierzchoń T. New estimate of phase sequence in diffusive layer formed on plasma nitrided Ti-6Al-4V alloy. Surf Coat Tech. 2014;259:473-82. http://dx.doi.org/10.1016/j. surfcoat.2014.10.043.

20. Raveh A, Bussiba A, Bettelheim A, Katz Y. Plasma-nitrided $\alpha-\beta$ Ti alloy: layer characterization and mechanical properties modification. Surf Coat Tech. 1993;57(1):19-29. http:// dx.doi.org/10.1016/0257-8972(93)90332-I.

21. Briguente LANS. Estudo de tratamento térmico e recobrimento como forma de barreira térmica sobre o comportamento em fluência da liga Ti-6Al-4V [dissertation]. São José dos Campos: Instituto Tecnológico de Aeronaútica; 2011.

22. Sugahara T. Estudo em fluência e caracterização microestrutural da liga Ti-6Al-4V recoberta com filme de $\mathrm{SiC}$ e intercamada de Cr por HiPIMS [thesis]. São Paulo: Universidade Federal de São Paulo; 2016.

23. Oliveira VMCA, Vazquez AM, Aguiar C, Robin A, Barboza MJR. Nitride coatings improve Ti-6Al-4V alloy behavior in creep tests. Mater Sci Eng A. 2016;670:357-68. http:// dx.doi.org/10.1016/j.msea.2016.06.041.

24. Sai Srinadh KV, Singh V. Oxidation behaviour of the near $\alpha$-titanium alloy IMI 834. Bull Mater Sci. 2004;27(4):34754. http://dx.doi.org/10.1007/BF02704771. 
25. Reis AG, Reis DAP, Abdalla AJ, Couto AA, Otubo J. Shortterm creep properties and fracture surface of $18 \mathrm{Ni}(300)$ maraging steel plasma nitrided. Mater Res. 2017;20(Suppl. 2):2-9. http://dx.doi.org/10.1590/1980-5373-mr-2016-0744.

26. Davari N, Rostami A, Abbasi SM. Effects of annealing temperature and quenching medium on microstructure, mechanical properties as well as fatigue behavior of Ti-6Al-4V alloy. Mater Sci Eng A. 2017;683:1-8. http://dx.doi.org/10.1016/j.msea.2016.11.095.
27. Katani S, Madadi F, Atapour M, Ziaei Rad S. Micromechanical modelling of damage behaviour of Ti-6Al-4V. Mater Des. 2013;49:1016-21. http://dx.doi.org/10.1016/j. matdes.2013.02.021.

28. Seco FJ, Irisarri AM. Creep failure mechanisms of a Ti-6Al-4V thick plate. Fatigue Fract Eng Mater Struct. 2001;24(11):741-50. http://dx.doi.org/10.1046/j.14602695.2001.00426.x. 